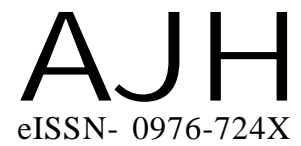

Received : 08.10.2017

Accepted : 30.11 .2017

Author for correspondence :

MADHURI SHRIKANT

SONAWANE

School of Agricultural Sciences, Yashwantrao Chavan

Maharashtra Open University, NASHIK (M.S.) INDIA
THEASIAN JOURNALOF HORTICULTURE

Volume 12 | Issue 2 | December, 2017 | 267-271

Visit us -www.researchjournal.co.in
DOI : 10.15740/HAS/TAJH/12.2/267-271

A REVIEW

\section{Nutritive and medicinal value of dragon fruit}

\section{MADHURI SHRIKANT SONAWANE}

ABSTRACT : Dragon fruit or pitahaya (Hylocereus spp.) is considered as a heavenly fruit on the earth. It is eaten as fresh or dried fruit, as a vegetable, as a fodder, as a natural colouring agent in various drinks and beverages, as a pectin source. Most importantly, being rich in various nutrients, vitamins and minerals and accordingly owing high medicinal values, it is believed to able to lower cholesterol concentration, to balance blood sugar concentration, to prevent colon cancer, to strengthen kidney function and bone, to strengthen the brain workings, increasing the sharpness of the eyes and even used in cosmetic ingredients. In a present investigation attempt has been made to explore the available research studies to prove or disprove the claims of its high nutritive and medicinal values.

KEY WORDS : Dragon fruit, Pitayaha, Nutritive value, Medicinal value, Food dye, Pectin

HOW TO CITE THIS ARTICLE : Sonawane, Madhuri Shrikant (2017). Nutritive and medicinal value of dragon fruit. Asian J. Hort., 12(2) : 267-271, DOI : 10.15740/HAS/TAJH/12.2/267-271. 